\title{
Herpesviruses associated with mortalities among hatchery-reared larval Pacific oysters Crassostrea gigas
}

\author{
P. M. Hine ${ }^{1}$, B. Wesney ${ }^{1}$, B. E. Hay ${ }^{2}$ \\ ${ }^{1}$ Fisheries Research Centre, Ministry of Agriculture and Fisheries, PO Box 297, Wellington, New Zealand \\ ${ }^{2}$ AquaBio Consultants Ltd, PO Box 560, Auckland 1, New Zealand
}

\begin{abstract}
Larvae of hatchery-reared Pacific oysters Crassostrea gigas Thunberg ceased feeding 3 to $4 \mathrm{~d}$ after spawning, and 60 to $100 \%$ mortalities accurred after 7 to $11 \mathrm{~d}$. Up to $25 \%$ of moribund larvae had putative phagocyte precursors and fibroblasts with enlarged nuclei of abnormal shape and chromatin pattern, which contained ovoid to hexagonal, non-enveloped, $97 \pm 4 \mathrm{~nm}$ diameter capsids and nucleocapsids of a herpes-like virus. Nucleocapsids became enveloped and de-enveloped as they passed through the nuclear membranes. Some became enveloped in intranuclear sacs containing tubular elements. Naked cytoplasmic nucleocapsids became enveloped by budding into vesicles or Golgi cisternae, and probably acquired a tegument from large dense granular masses near Golgi complexes. Extracellular enveloped virions usually had a tegument, and were $131 \pm 9 \mathrm{~nm}$ in diameter Extracellular naked nucleocapsids were thought to derive from lysed cells. Non-enveloped ovoid to hexagonal $86 \pm 12 \mathrm{~nm}$ virions, thought to be degraded herpesvirions, were abundant in inter-digitating processes of putative phagocytes in $>50 \%$ of moribund larvae. Comparison with groups within the Herpesviridae was made, and similarities to cytomegaloviruses noted. Elevated temperature and crowding may increase susceptibility of oyster larvae to herpes-like virus infection.
\end{abstract}

\section{INTRODUCTION}

Pacific or Japanese oysters Crassostrea gigas Thunberg are increasingly being cultured in many countries, from stocks ultimately originating from Japan. Whereas introductions into North America, Europe and Australia (Tasmania) were by human agency, C. gigas was first reported in New Zealand in 1971 (Dinamani 1971), and was probably accidently introduced on Japanese vessels in the late 1960's (Smith et al. 1986). In many cases movement of $C$. gigas has occurred before adequate disease studies could be undertaken, and therefore international movement of $C$. gigas stocks may have resulted in the spread of pathogens of $C$. gigas. The international movement of spat poses a continuing risk of disease introduction, until pathogens in such spat have been identified.

Three viral diseases have been reported from Crassostrea gigas. All 3 were caused by iridoviruses, 2 of which occurred in adult C. gigas (syn. C. angulata) in France (Comps 1988). The third iridovirus caused Oyster Velar Virus Disease (OVVD) in hatchery-reared larval C. gigas in the northwest United States (Elston \& Wilkinson 1985). Four viruses have been reported from Crassostrea virginica in the northeast United States, a herpes-type virus in oysters held at elevated temperatures (Farley et al. 1972), a papovavirus and a retrovirus (Farley 1978), and a reo-like virus in juvenile oysters (Meyer 1979). Herpesviruses have also been observed in cells with Cowdry type A inclusions in about $4 \%$ of oysters Ostrea edulis in North Wales during summer (Alderman 1980, pers. comm.).

In mid-summer (February) 1991 mass (60 to 100\%) mortalities occurred in larval Crassostrea gigas in a hatchery at Mahurangi, $40 \mathrm{~km}$ north of Auckland, New Zealand, and moribund larvae were examined under the electron microscope. This paper reports the presence and appearance of herpesviruses in those larvae.

\section{MATERIALS AND METHODS}

Ten consecutive batches of larvae from locally collected wild oysters Crassostrea gigas in spawning con- 
dition were held in tanks of filtered $(10 \mu \mathrm{m})$ seawater at 24.0 to $25.5^{\circ} \mathrm{C}$, with water changed every 2 to $3 \mathrm{~d}$. Mortality was estimated from the proportion of larvae in the water column (healthy), or alive but unable to swim normally (moribund), to those that were dead. Wild larvae from plankton taken near the hatchery, and moribund and healthy hatchery-reared larvae sampled daily 7 to $10 \mathrm{~d}$ after spawning, were fixed in $2.5 \%$ glutaraldehyde in $0.22 \mu \mathrm{m}$ filtered seawater for 1 to $2 \mathrm{~h}$, washed twice in filtered seawater, and centrifuged to form a pellet; the seawater was removed and replaced by $2 \%$ molten $\left(50^{\circ} \mathrm{C}\right)$ agar. The pellet in agar was transferred to a slide and cut to small pieces in $0.1 \mathrm{M}$ cacodylate buffer, post-fixed in $1 \% \mathrm{OsO}_{4}$ in $0.1 \mathrm{M}$ cacodylate for $1 \mathrm{~h}$, de-calcified in $5 \%$ EDTA (ethylenediaminetetra-acetuc acid) in $0.1 \mathrm{M}$ cacodylate for 30 to $45 \mathrm{~min}$, wahsed in $0.1 \mathrm{M}$ cacodylate, dehydrated in an ethanol series (50 to $100 \%$ ), washed twice for $10 \mathrm{~min}$ in propylene oxide, infiltrated for $1 \mathrm{~h}$ in $50 /$ 50 propylene oxide/araldite resin, embedded in $100 \%$ resin overnight, and cured for $48 \mathrm{~h}$ at $60^{\circ} \mathrm{C}$. Ultrathin sections were cut and stained in $5 \%$ uranyl acetate in $50 \%$ ethanol for $10 \mathrm{~min}$ and $5 \%$ lead citrate in boiled distilled water for $5 \mathrm{~min}$, and examined under a Philips 201 transmission electron microscope.

\section{RESULTS}

\section{Course of disease}

Larval growth slowed, and in most cases ceased, 3 to 4 $\mathrm{d}$ after spawning, coinciding with reduction in feeding and swimming activity. Significant (> $60 \%$ ) mortality occurred by Day 7 , with $100 \%$ mortality by Day 11 in most batches. Moribund larvae swam weakly in circles with their vela noticeably less extended than in healthy larvae. Dead larvae measured 75 to $80 \mu \mathrm{m}$ and were all at the straight-hinge (D) stage. Larvae surviving until $12 \mathrm{~d}$ went on to settle normally. Healthy larvae reached $120 \mu \mathrm{m}$ and entered the umbo stage at $7 \mathrm{~d}$, with settlement at 21 to $28 \mathrm{~d}$ when larvae reached 300 to $350 \mu \mathrm{m}$.

\section{Ultrastructural observations}

In ca $10 \%$ of Day- 7 and ca $25 \%$ of Day-9 moribund hatchery larvae, enlarged cells with hypertrophied nuclei, marginated chromatin and intranuclear inclu- sions (Fig, 1) contained capsids and nucleocapsids (Fig. 2). Capsids concentrated near ovoid or ring-shaped fine granular masses were empty, or contained a loose central aggregation of fine granular material similar to that of the nuclear inclusion (Figs. 1, $3 \& 4$ ). Nucleoid formation or acquisition was not observed, even though nucleocapsids that lacked a tegument and envelope were scattered throughout the nucleus (Fig. 2). However, membrane-bound intranuclear sac-like inclusions near the nuclear periphery contained enveloped virions, and membranous tubular ( $25 \mathrm{~nm}$ diameter) or vesicular structures (Figs. 2 \& 5). Enveloped virions were also observed in the perinuclear cisterna (Fig. 6), but most nucleocapsids appeared to enter the cytoplasm without an envelope. Reduplication of the nuclear membrane was not observed. A few large dense granular bodies, lacking a bounding membrane, and closely associated Golgi bodies of normal appearance were observed in each infected cell. Nucleocapsids around the dense bodies (Fig. 7) and nearby Golgi (Fig. 8) were enveloped by budding into vesicles or cisternae. Cytoplasmic nucleocapsids were also seen near large vesicles or cisternae containing a fine reticulated matrix, into which they passed (Fig. 9) and became enveloped (Fig. 10). Whether these large vesicles/cisternae originated from Golgi or the nuclear membrane was unclear. Only naked cytoplasmic nucleocapsids were observed in the cytoplasm of myocytes containing non-striated fibrils (Fig, 11), which were probably adductor muscle cells, but enveloped tegumented single virions were observed in cytoplasmic vesicles in other cells (Fig. 12). Extracellular virions were usually enveloped and had spike-like protrusions on the surface (Fig. 13) or occasionally had a tail (Fig. 14). Degenerating and lysing infected nuclei were frequently observed (Fig. 15). The locations of different stages occurring in cellular compartments are shown in Table 1

Mature virions consisted of a hexagonal or toroidal core that was $12 \mathrm{~nm}$ inside diameter, $66 \mathrm{~nm}$ across (Fig. 13), and $43 \mathrm{~nm}$ in depth, when viewed longitudinally (Fig. 16). The toroid was enclosed by an elongated hexagonal to ovoid capsid, $97 \pm 4 \mathrm{~nm}(\mathrm{n}=50)$ in diameter, with fine fibrils spanning the lucent space from core to capsid (Figs. $9 \& 16$ ). Enveloped virions, $131 \pm 9 \mathrm{~nm}(\mathrm{n}=50)$ across, were bounded by a unit membrane and the tegument appeared electron-dense (Fig. 13). Other than fibroblasts, the infected cell types could not be identified with certainty, but nucleocap-

Figs. 1 to 4. Herpes-like virus infecting Crassostrea gigas larvae. Fig. 1. Section showing enlarged cells (arrows) with hypertrophied nuclei that contain marginated chromatin and an intranuclear inclusion (arrowhead); $\times 5950$. Fig. 2. Part of an enlarged cell showing intranuclear capsids (c), nucleocapsids (nc) and an intranuclear sac (is), extracellular tegumented virions (ev) and partially enveloped nucleocapsid (arrow); $\times 47960$. Fig. 3. Ring-shaped fine granular intranuclear inclusion; $\times 30000$. Fig. 4. Intranuclear fine granular inclusion bordered by capsids containing similar granular material; $\times 50000$ 


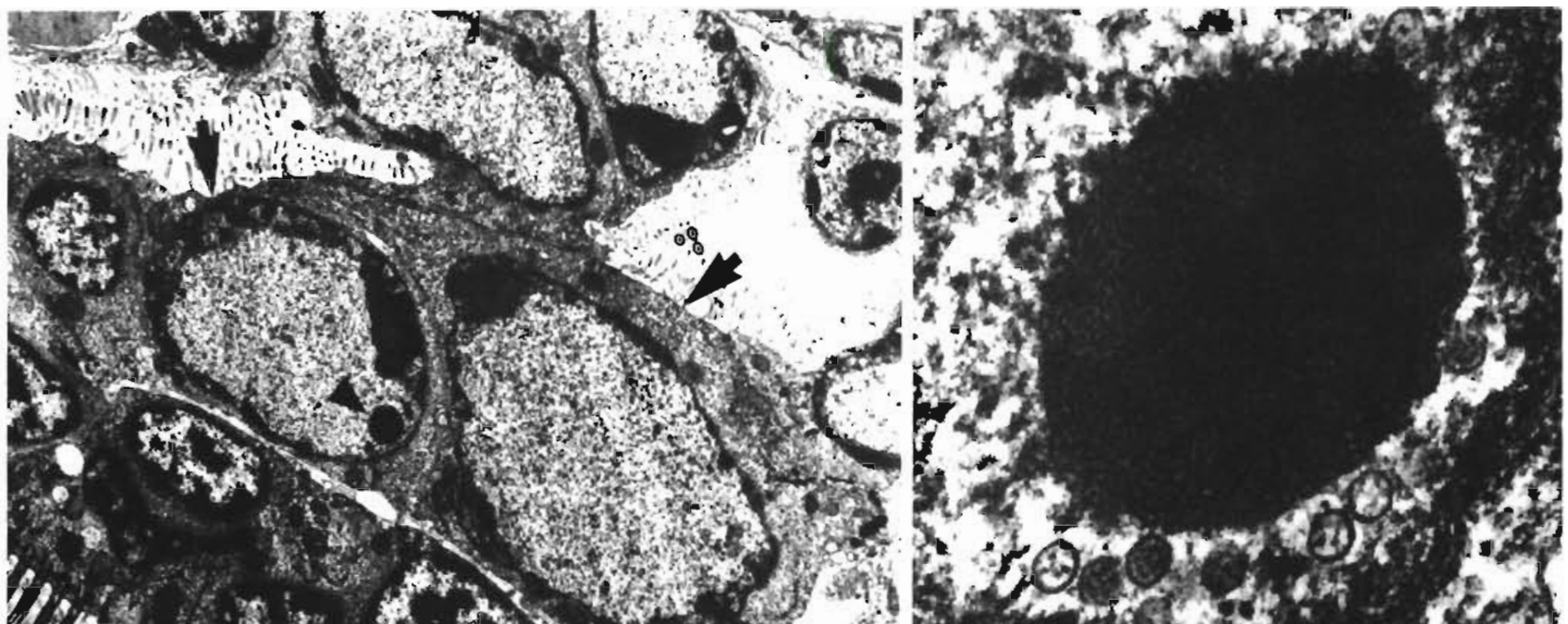

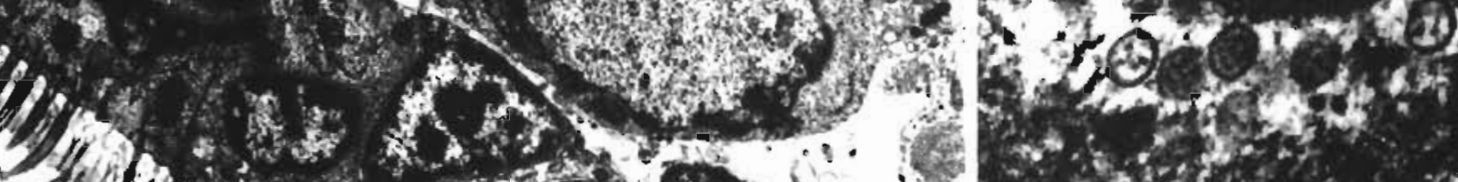

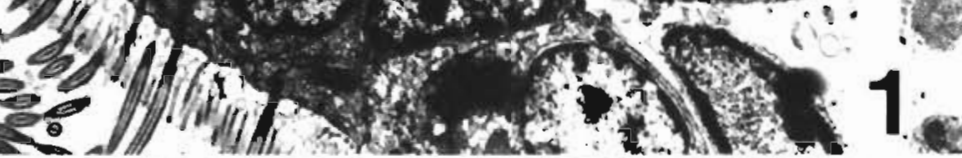

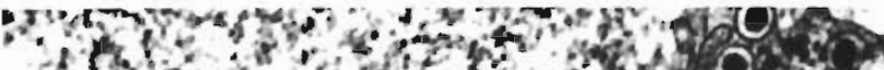

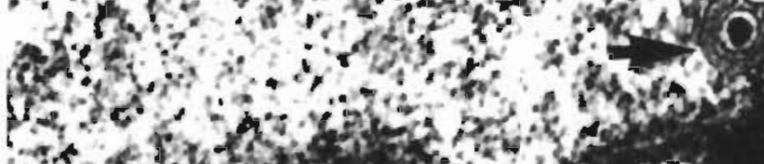

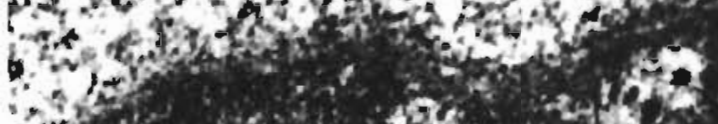

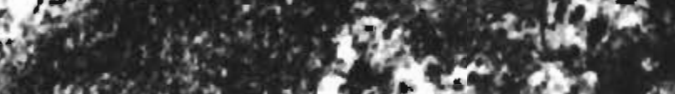

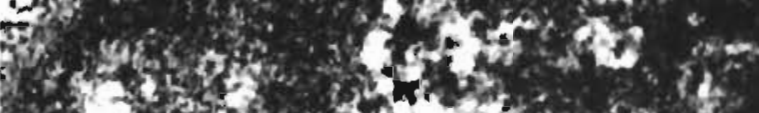

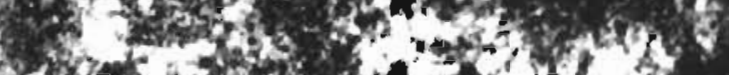

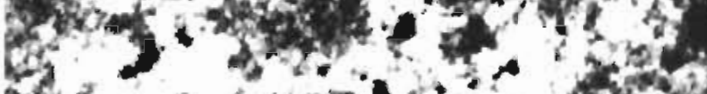

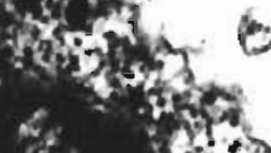

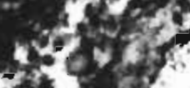
")

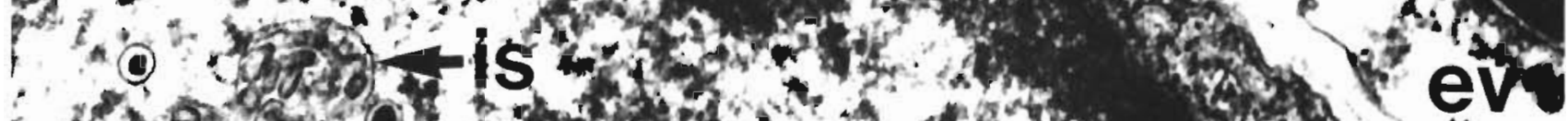

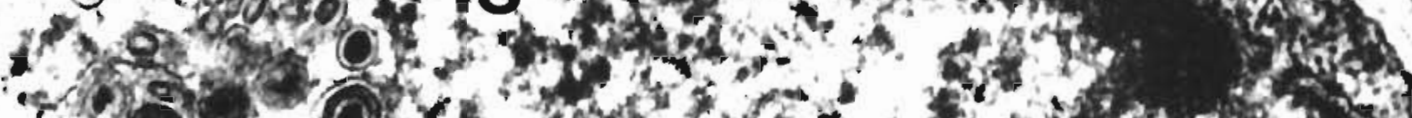

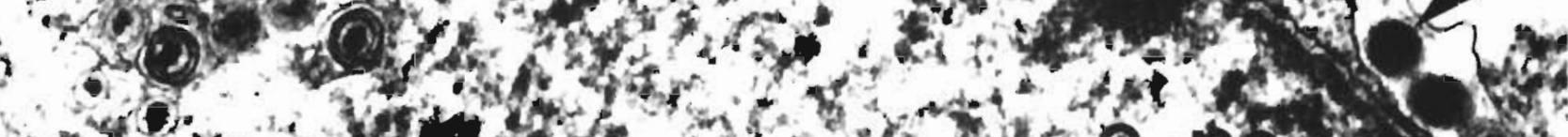

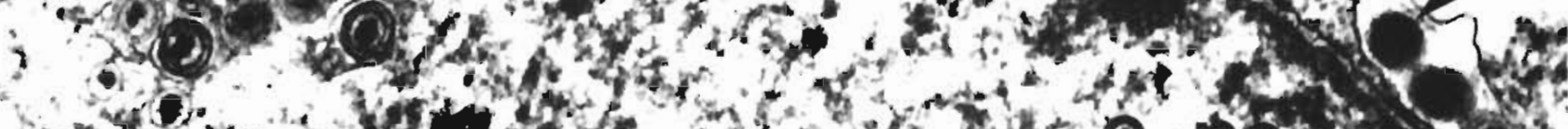

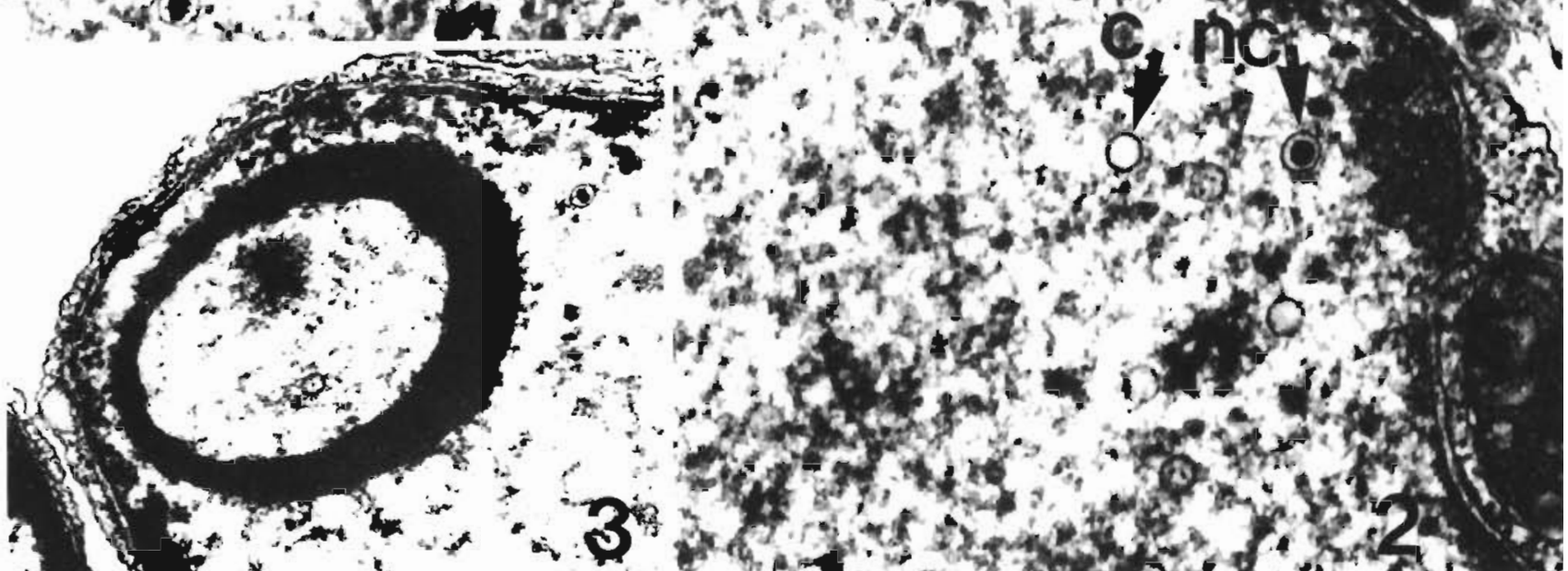




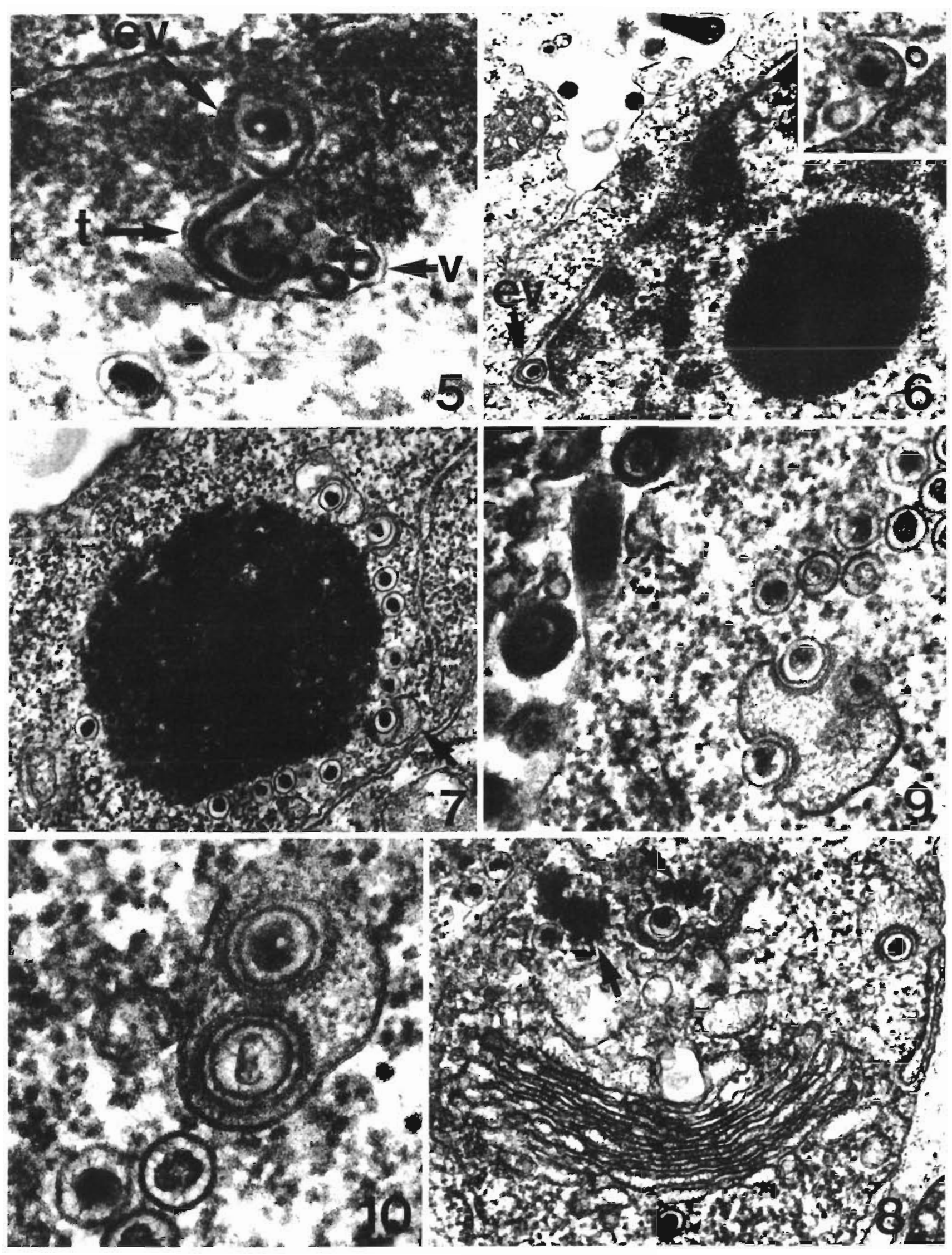


Table 1. Occurrence of different stages of replication of oyster herpes-like virus in different cellular and extracellular compartments of Crassostreas gigas larvae

\begin{tabular}{|c|c|c|c|c|c|}
\hline Compartment & Capsids & Nucleocapsids & $\begin{array}{l}\text { Enveloping } \\
\text { virions }\end{array}$ & $\begin{array}{l}\text { Enveloped } \\
\text { virions }\end{array}$ & $\begin{array}{l}\text { Enveloped and } \\
\text { tegumented virions }\end{array}$ \\
\hline Nucleus & + & + & & & \\
\hline Intranuclear sac & & & & + & \\
\hline Perinuclear space & & & & + & \\
\hline Cytoplasm & & + & + & & \\
\hline Dense bodies & & + & + & + & + \\
\hline Golgi apparatus & & + & + & + & + \\
\hline Cytoplasmic vesicles & & & & + & + \\
\hline Extracellular & & + & & + & + \\
\hline
\end{tabular}

sids 87 to $89 \mathrm{~nm}$ in diameter occurred in inter-digitating cells (Fig. 17) that might have been phagocyte (haemocyte) precursors (R. Elston pers. comm.).

Putative degenerating capsids and nucleocapsids were observed in inter-digitating cells of $<50 \%$ of wild larvae and $>50 \%$ of moribund hatchery larvae. They were hexagonal to ovoid in shape, $86 \pm 12 \mathrm{~nm}(\mathrm{n}=50)$ in diameter, with a granular core (Fig. 18).

\section{DISCUSSION}

The virions described resemble herpesviruses in size, the toroidal core, possession of an envelope with surface spikes, amorphous tegument, nucleocapsid assembly in the nucleus and occurrence of enveloped virions at the nuclear membrane or in vesicular cytoplasmic spaces or cisternae (Roizman et al. 1981, Murphy \& Kingsbury 1990, Roizman 1990). In addition, the fibrils running from the inner surface of the capsid to the torus are similar to the arrangement in herpesvirions (Furlong et al. 1972, Roizman 1990). From the occurrence of different stages in different cellular compartments (Table 1), it seems nucleocapsids are formed in the nucleus, pass through the inner nuclear membrane to become enveloped in the perinuclear space, and lose the envelope on passing through the outer membrane into the cytoplasm. Intranuclear sacs may be invaginations of the inner nuclear membrane into the nucleus. In the cytoplasm, nucleocapsids congregate at dense body/Golgi complexes, where they bud into Golgi cisternae to become enveloped with or without an amorphous dense tegument that probably derives from the dense body. Enveloped virions in vesicles are released at the cell surface. Extracellular naked nucleocapsids may derive from lysed infected cells.

The herpesviruses reported here show similarities to some members of the Alphaherpesvirinae (the simplexviruses), such as channel catfish virus, in the appearance of the fine granular intranuclear inclusions (Wolf \& Darlington 1971). The oyster viruses differ from simplexviruses in lack of reduplication of the nuclear membrane (Smith \& de Harven 1973) or modification of the inner nuclear membrane before envelopment (Campadelli-Fiume et al. 1991). Also, simplexviruses are enveloped on budding through the inner nuclear membrane and remain enveloped as they pass down a labyrinth of endoplasmic reticulum, vesicles or cisternae and out of the cell. Thus naked nucleocapsids are seldom observed in the cytoplasm, except for mutant strains (Campadelli-Fiume et al. 1991). Simplexviruses have intranuclear sacs termed tegusomes (Roffman et al. 1990), in which the tegument is formed. The sacs lack tubular elements and often contain cytoplasmic structures (Wolf \& Darlington 1971), and are therefore unlike those observed here. Dense bodies are not involved in transit of virions through the cytoplasm.

This oyster virus more closely resembles the Betaherpesvirinae [the cytomegaloviruses (CMV)] in the enlargement of infected cells and their nuclei (Roizman et al. 1981), the presence of intranuclear sacs containing

Figs. 5 to 10 . Herpes-like virus infecting Crassostrea gigas larvae. Fig. 5. Intranuclear sac containing enveloped virion (ev) and tubular ( $t$ ) and vesicular (v) structures; $\times 120000$. Fig. 6. Enveloped virion (ev) in the perinuclear space near fine granular inclusion $(\times 36000)$, and detail of enveloped virion (inset; $\times 96000)$. Fig. 7 . Dense granular cytoplasmic body surrounded by nucleocapsids, some of which are becoming enveloped by cytoplasmic vesicles or cisternae (arrow); $\times 44330$. Fig. 8 . Golgi profile showing dense granular material (arrows) and cisternae containing granular material around naked nucleocapsids; $\times 56250$. Fig. 9. Nucleocapsids budding into vesicle or cisterna containing reticulated material. Note nearby naked nucleocapsids and extracellular enveloped virions with a dense tegument; $\times 90060$. Fig. 10. Enveloped virions within vesicle or cisterna, and unenveloped nucleocapsids free in the cytoplasm; $\times 154620$ 


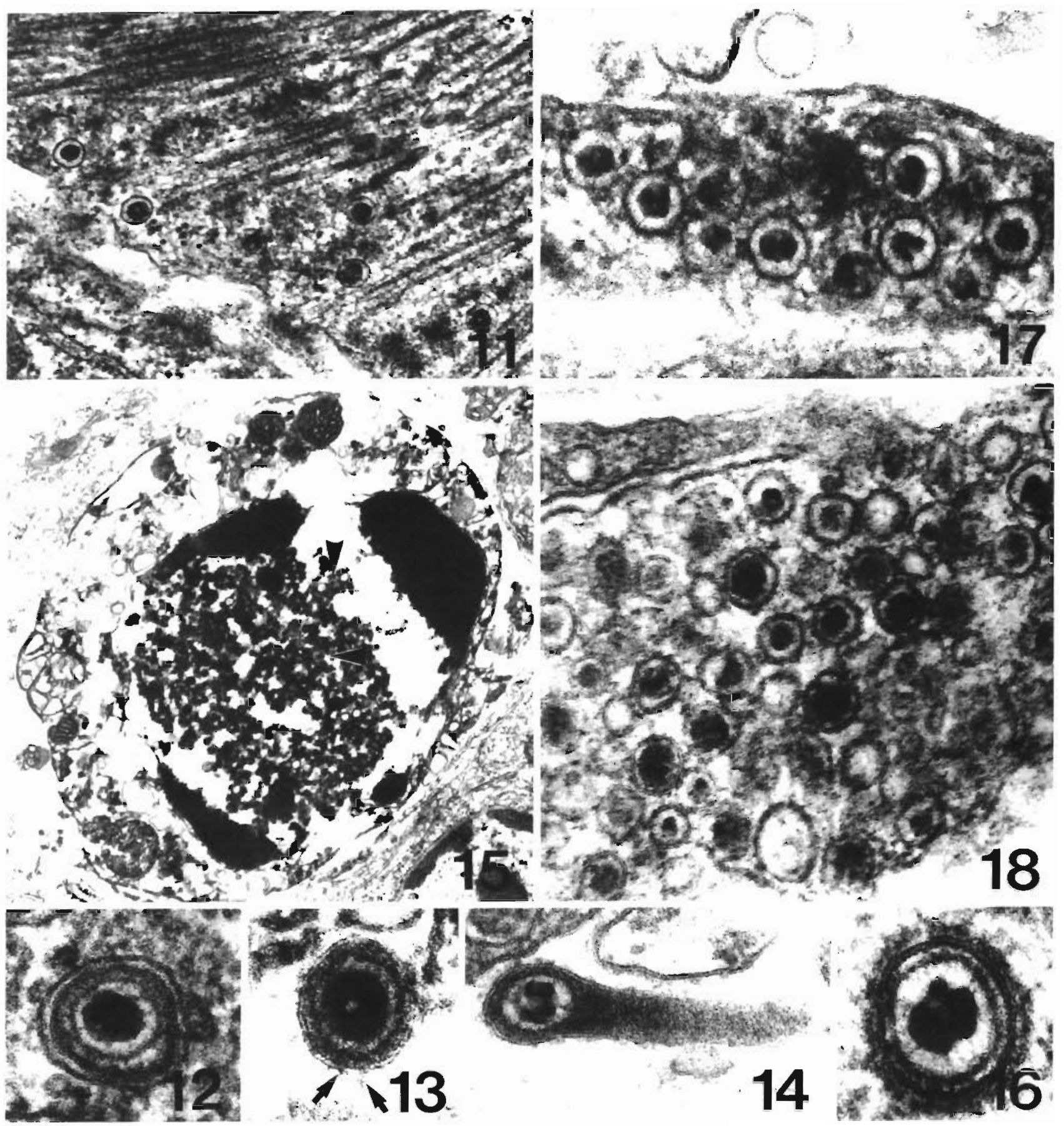

Figs. 11 to 18. Herpes-like virus infecting Crassostrea gigas larvae. Fig. 11. Myocyte cytoplasm containing unenveloped nucleocapsids; $\times 52780$. Fig. 12. Enveloped tegumented virion within a cytoplasmic vesicle; $\times 143930$. Fig. 13. Extracellular enveloped tegumented virion showing the toroidal core and surface spikes (arrows); $\times 173900$. Fig. 14. Extracellular enveloped virion with a tail containing amorphous tegument; $\times 121890$. Fig. 15. Lysed nucleus showing intranuclear nucleocapsids (arrowheads): $\times 17630$. Fig. 16. Enveloped virion showing a longitudinal section of the toroidal core and fine filaments passing from it to the inside of the capsid; $\times 210690$. Fig. 17 . Inter-digitating portion of cell containing nucleocapsids with a toroidal core; $\times 116000$. Fig. 18. Inter-digitating portion of cell showing nucleocapsids containing granular pleomorphic cores; $\times 110400$

tubular elements (Tumilowicz \& Powell 1990), the temporary envelopment and de-envelopment as nucleocapsids pass through the nuclear membrane (Severi et al. 1979), and their association with dense bodies and Golgi in the cytoplasm (Severi et al. 1988). The ovoid ring of nuclear granular material (Fig, 4) is similar to that reported in human cytomegalovirus infection (Tumilowicz \& Powell 1990). If cessation of feed- 
ing by Crassostrea gigas larvae at 3 to $4 \mathrm{~d}$ indicates onset of infection, and most deaths occur at 9 to $10 \mathrm{~d}$, replication may occur over ca $6 \mathrm{~d}$, as in CMV (Smith \& de Harven 1973, Roizman et al. 1981), although several replication cycles may occur over this period. In $C$. virginica, the free intranuclear tubular structures in herpesvirus infection (Fig. 3 in Farley et al. 1972) closely resemble intranuclear tubules in CMV infection (Fig. 2 in Fong et al. 1979). However, the large characteristic intranuclear inclusions of CMV (Fons \& Albrecht 1986) have not been observed in this study, and the multiple dense bodies of CMV pass with virions out of the cell (Fong et al. 1979). The peripheral vesicles around dense bodies and 'black holes' reported from CMV infection (Severi et al. 1988) were also not observed here. Despite this, the general process of CMV replication outlined by Severi et al. (1988: Fig. 10, routes A/A1, B and C) is similar to larval oyster herpes-like virus replication.

The replication of Gammaherpesvirinae (saimiriateles viruses) also involves intranuclear sacs with tubular elements and many dense fibrillar bodies (Tralka et al. 1977, Luetzeler et al. 1979), but intranuclear tubular lamella-particle complexes (Tralka et al. 1977), intranuclear electron-dense granules and occurrence of nucleocapsids within dense bodies (Luetzeler et al. 1979) were not observed here. More importantly, the specificity of gammaherpesviruses for $\mathrm{T}$ and $\mathrm{B}$ lymphocytes (Roizman et al. 1988) makes invertebrate infection unlikely.

The larval oyster herpesvirus may appear, on the basis of transmission electron microscopy (TEM), to be more similar to the Betaherpesvirinae than to the other 2 herpesvirus sub-families, but such similarities cannot be taken to indicate affinities. Details of replication are variable within sub-families (Dargan 1986) and vary with cell type infected (Tralka et al. 1977, Dargan 1986), strain of virus (Campadelli-Fiume et al. 1991) and time after infection (Severi et al. 1988), and the variables concerned need to be tested before a general pattern can be determined. Herpesviruses of aquatic organisms are poorly defined at present, and further studies may well establish further sub-families within the Herpesviridae.

There have been several reports of herpesviruses or herpes-like viruses from aquatic animals (Buchanan \& Richards 1982, Hedrick \& Sano 1989, Hedrick et al. 1990), some of which cause typical Cowdry type A inclusions (Buchanan \& Richards 1982, Sano et al. 1985, Hedrick \& Sano 1989), including herpes-type viruses in oysters (Farley et al. 1972, Alderman 1980). The nucleocapsids described here are similar in dimension to those of other aquatic herpesviruses, including those observed in Ostrea edulis by Alderman (1980, pers. comm.), but at $97 \pm 4 \mathrm{~nm}$ they are larger than the 70 to $90 \mathrm{~nm}$ of nucleocapsids described from Crassostrea virginica by Farley et al. (1972). However, virion dimensions depend on the method of measurement and specimen preparation, and the herpesviruses of oysters may be conspecific.

The method by which larvae become infected is unknown, but Meyers (1981) reported Cowdry type A inclusions in the mantle epithelial cells of an adult Crassostrea virginica in spring from Long Island, USA. The mantle epithelium is an ideal site for shedding viruses, and it may be that eggs or larvae are infected by virions shed by the parent oyster around spawning. However, the presence of virions in these Cowdry type A inclusions needs to be confirmed by TEM.

In this study growth and development of larvae were retarded, presumably because of cessation in feeding, and mortality was high. Virus-associated mortalities were confined to between 7 and $11 \mathrm{~d}$ after spawning, beyond which larvae appeared refractory to the virus. Herpesviruses of marine organisms may cause disease under crowded, stressed conditions at elevated temperatures (Buchanan \& Richards 1982), as here, although such conditions favour pathogens in general, and do not apply to all aquatic herpesviruses (Skinner \& Mizell 1972, Hedrick et al. 1990). However, the occurrence of herpesviruses and mortalities in summer in Ostrea edulis in North Wales (Alderman 1980), the presence of herpesviruses in oysters held at elevated temperatures in Maine (Farley et al, 1972), and the occurrence of mortalities in mid-summer in this study suggest oyster herpesviruses may only be a problem at elevated temperatures, particularly under crowded hatchery conditions. If this virus has affinities with the Betaherpesvirinae, it is likely to have narrow host specificity and may be specific to ostreids.

Acknowledgements. We are grateful to Dave Alderman for supplying light and electron micrographs of the North Wales herpesvirus, and to Ralph Elston for his identification of larval cell types. Also the help and advice of Les Curtin on Pacific oysters, and preparation of samples for electron microscopy by Karen Reader of Victoria University of Wellington, are gratefully appreciated.

\section{LITERATURE CITED}

Alderman, D. J. (1980). Shellfish diseases, past, present and future. In: Proc. 11th Ann. Conf. Shellfish Assoc. Great Britain, p. $30-40$

Buchanan, J. S., Richards, R. H. (1982). Herpes-type virus diseases of marine organisms. Proc. R. Soc. Edinb. 81B: $151-168$

Campadelli-Fiume, G., Farabegoli, F., Di Gaeta, S., Roizman, B. (1991). Origin of unenveloped capsids in the cytoplasm of cells infected with Herpes Simplex Virus 1. J. Virol. 65: $1589-1595$

Comps, M. (1988). Epizootic diseases of oysters associated with viral infections. In: Fisher, W. S. (ed.) Disease pro- 
cesses in marine bivalve molluscs. Arn. Fish. Soc. Spec. Publ. 18: 23-37

Dargan, D. J. (1986). The structure and assembly of herpesviruses. In: Harris, J. R. (ed.) Electron microscopy of proteins, 5. Viral structure. Academic Press, New York, p $359-43$ ?

Dinamani, P. (1971). Occurrence of the Japanese oyster, Crassostrea gigas (Thunberg), in Northland, New Zealand, N.Z. J. mar Freshwat. Res. 5: 352-357

Elston, R. A., Wilkinson, M. T. (1985). Pathology, management and diagnosis of oyster velar virus disease. Aquaculture 48: $189-210$

Farley, C. A. (1978). Viruses and virus-like lesions in marine mollusks. Mar. Fish. Rev. 40(10): 18-20

Farley, C. A., Banfield, W. G., Kasnic, G., Foster, W. S. (1972). Oyster Herpes-type virus. Science 178: 759-760

Fong, C. K. Y., Bia, F., Hsuing, G.-D., Madore, P., Chang, P.-W. (1979). Ultrastructural development of guinea pig cytomegaiovirus in cuitured guinea-pig embryo cells. J. gen. Virol. 42: 127-140

Fons, M., Albrecht, T (1986). Cytomegalovirus: the relationship of nucleocapsid assembly to the organization of the cellulae. Arch. Virol. 91: 351-356

Furlong, D., Swift, H., Roizman, B. (1972). Arrangement of herpesvirus deoxyribonucleic acid in the core. J. Virol. 10: 1071-1074

Hedrick, R. P., Groff, J. M. Okihiro, M. S., McDowell, T. S. (1990). Herpesviruses detected in papillomatous skin growths of koi carp (Cyprinus carpio). J. Wildl. Dis. 26: 578-581

Hedrick, R. P., Sano, T (1989). Herpesviruses of fish. In: Ahne, W., Kurstak, E. (eds.) Viruses of lower vertebrates. Springer-Verlag, Berlin, p. 161-170

Luetzeler, J., Heine, U. I., Wendel, E., Prasad, U., Ablash, D. V (1979). Ultrastructural studies on the replication of Herpes Ateles-73 in owl monkey kidney cells. Arch. Virol. 60: $59-73$

Meyers, T. R. (1979). A reo-like virus isolated from juvenile American oysters (Crassostrea virginica). J. gen. Virol. 43: 203-212

Meyers, T R. (1981). Endemic diseases of cultured shellfish of Long Island, New York: adult and juvenile American oys-

Responsible Subject Editor: A. K. Sparks, Seattle, Washington, USA ters (Crassostrea virginica) and hard clams (Mercenana mercenaria). Aquaculture 22: 305-330

Murphy, F. A., Kingsbury, D. W. (1990). Virus taxonomy. In: Fields, B. N., Knipe, D. M. (eds.) Virology. Raven Press, New York, p. 9-35

Roffman, E., Albert, J. P., Goff, J. P., Frenkel, N. (1990). Putative site for the acquisition of human herpesvirus 6 virion tegument. J. Virol, 64: 6308-6313

Roizman, B. (1990). Herpesviridae: a brief introduction. In: Fields, B. N., Knipe, D. M. (eds.) Virology. Raven Press, New York, p. 1787-1793

Roizman, B., Carmichael, L. E., Deinhardt, F., de-The, G., Nahmias, A. J., Plowright, W., Rapp, F., Sheldrick, P., Takahashi, M., Wolf, K. (1981). Herpesviridae. Intervirology 16: 201-217

Sano, T., Fukuda, H., Furukawa, M. (1985). Herpesvirus cyprini: biological and oncogenic properties. Fish Path. 20: $381-388$

Severn, B., Landıni, M. P., Govoni, E. (1988). Human cytomelagovirus morphogenesis: an ultrastructural study of the late cytoplasmic phases. Arch. Virol. 98: 51-64.

Severi, B., Landini, M. P., Musiani, M., Zerbini, M. (1979). A study of the passage of human megalovirus from the nucleus to the cytoplasm. Microbiologica 2: 265-273

Skinner, M. S., Mizell, M. (1972). The effect of different temperatures on herpesvirus induction and replication in Lucké tumor explants. Lab. Invest. 26: 671-681

Smith, J. D., de Harven, E. (1973). Herpes simplex virus and human cytomelagovirus replication in WI-38 cells. I. Sequence of viral replication. J. Virol. 12: 919-930

Smith, P. J., Ozaki, H., Fujio, Y. (1986). No evidence for reduced genetic variation in the accidentally introduced oyster Crassostrea gigas in New Zealand. N.Z. J. mar Freshwat. Res. 20: 569-574

Tralka, T. S., Costa, J., Rabson, A. (1977). Electron microscopic study of herpesvirus saimiri. Virology 80: 158-165

Tumilowicz, J. J., Powell, B. B. (1990). Role of intranuclear sacs, intrasaccate tubes, and cytoplasmic dense bodies in the structural completion of cytomelagovirus. Intervirology 31: $14-22$

Wolf, K., Darlington, R. W. (1971). Channel catfish virus: a new herpesvirus of ictalurid fish. Virology 12: 204-224

Manuscript first received: June 10, 1991

Revised version accepted: December 9, 1991 